\title{
A Dye-Sensitized Solar Cell Using a Composite of PEDOT:PSS and Carbon Derived from Human Hair for a Counter Electrode
}

\author{
Klitsada Moolsarn, ${ }^{1}$ Apishok Tangtrakarn, ${ }^{1,2,3,4,5}$ Adulphan Pimsawat, ${ }^{2}$ Kornrawit Duangsa, \\ Charusporn Mongkolkachit, ${ }^{6}$ Wasan Maiaugree, ${ }^{2}$ and Vittaya Amornkitbamrung ${ }^{2,3,4,5}$ \\ ${ }^{1}$ Materials Science and Nanotechnology Program, Department of Physics, Faculty of Science, Khon Kaen University, Khon Kaen \\ 40002, Thailand \\ ${ }^{2}$ Department of Physics, Faculty of Science, Khon Kaen University, Khon Kaen 40002, Thailand \\ ${ }^{3}$ Integrated Nanotechnology Research Center, Khon Kaen University, Khon Kaen 40002, Thailand \\ ${ }^{4}$ Nanotec-KKU Center of Excellence on Advanced Nanomaterials for Energy Production and Storage, Khon Kaen University, Khon \\ Kaen 40002, Thailand \\ ${ }^{5}$ Thailand Center of Excellence in Physics, Commission on Higher Education, Bangkok 10400, Thailand \\ ${ }^{6}$ National Metal and Materials Technology Center, 114 Paholyothin Road, Klong 1, Klong Luang, Pathumthani 12120, Thailand
}

Correspondence should be addressed to Apishok Tangtrakarn; nateta@kku.ac.th

Received 18 January 2017; Revised 15 March 2017; Accepted 22 March 2017; Published 13 June 2017

Academic Editor: Yaohui Zhan

Copyright (c) 2017 Klitsada Moolsarn et al. This is an open access article distributed under the Creative Commons Attribution License, which permits unrestricted use, distribution, and reproduction in any medium, provided the original work is properly cited.

Carbon derived from hair is interesting because it has good electrocatalytic activity due to the existence of innate heteroatom dopants especially nitrogen and sulfur. In this study, a carbon catalyst containing high nitrogen contents (9.47 at.\%) was fabricated without using any harsh chemicals. Moreover, the carbonization temperature was only $700^{\circ} \mathrm{C}$. Carbonized hair/ PEDOT:PSS composites $\left(\mathrm{C}_{x} \mathrm{P}\right)$ with varied carbon contents from $x=0.2$ to $0.8 \mathrm{~g}$ were tested as a counter electrode (CE) for a dye-sensitized solar cell (DSSC). This type of DSSC CE has scarcely been investigated. A DSSC with a $\mathrm{C}_{0.6} \mathrm{P}$ CE provides the best efficiency $(6.54 \pm 0.11 \%)$ among all composite CEs because it has a high fill factor (FF) and a high short-circuit current density $\left(J_{\text {sc }}\right)$. The efficiency of DSSC with $\mathrm{C}_{0.6} \mathrm{P}$ CE is lower than Pt's $(7.29 \pm 0.01 \%)$ since the Pt-based DSSC has higher FF and $J_{\text {sc }}$ values. However, $\mathrm{C}_{0.6} \mathrm{P}$ is still promising as a DSSC CE since it is more cost-effective than Pt.

\section{Introduction}

A renewable energy source such as a dye-sensitized solar cell (DSSC) has been intensively studied due to its simple fabrication process and high solar conversion efficiency [1]. To construct a DSSC with high efficiency, one approach is to use a counter electrode (CE) material with high conductivity and excellent electrocatalytic activity. Among leading candidates for a DSSC CE is Pt [2]. Unfortunately, since Pt is expensive, employing a cheaper substitute becomes a stringent requirement. So far, there are cheaper alternative materials that can rival with $\mathrm{Pt}$ in terms of electrocatalytic performance such as nitrides [3], sulfides [4], carbides [5], and carbon allotropes. Various types of carbons that can function well as CE catalysts include graphites, carbon nanotubes, graphenes, reduced graphene oxides, activated carbons, carbon blacks, and biomass-derived charcoals (biochars) [6-13].

One of the procedures to produce a biochar catalyst for a DSSC application is to thermally carbonize biomass under reducing atmosphere at a high temperature of around $850^{\circ} \mathrm{C}[12,13]$. Furthermore, to improve the as-pyrolized carbon's electrocatalytic performance, additional chemical processing steps in order to increase the carbon's surface area may be required. Most of these chemical treatment processes involve the use of harsh chemicals [14-16], which can be a downside. Therefore, biomasses subjected to milder thermal/chemical treatment are of interest provided that each derived carbon still function as a good catalyst.

Human hair is a fascinating biochar source because it naturally contains nitrogen and sulfur atoms. It has been 
known that carbon doped with heterodopants such as nitrogen and sulfur usually have high electrocatalytic activity $[17,18]$. Yet, there were only a few reports involving applications of carbonized human hair as an electrochemical electrode. These reports demonstrated the use of carbonized hair as a supercapacitor electrode $[19,20]$ and as a CE of a quantum dot-sensitized solar cells (QDSSC) [13]. As for the QDSSC-related work, Sahasrabudhe et al. fabricated their QDSSC CEs by mixing carbonized-hair powder with a PVDF binder and an NMP solvent. Mechanical grinding was not used in their work because human hair was digested with concentrated sulfuric acid before carbonizing the human hair at $850^{\circ} \mathrm{C}$ for $6 \mathrm{~h}$. Without further chemical treatment of the carbon, their optimized QDSSC reached an efficiency of $4.44 \%$ in a polysulfide electrolyte.

In this study, we demonstrated the use of DSSC CE made of human hair catalyst mixed with a PEDOT:PSS binder. PEDOT:PSS (PEDOT) conducting polymer is a good choice because it has high conductivity and exhibits electrocatalytic activity toward converting tri-iodide $\left(\mathrm{I}_{3}^{-}\right)$into iodide $\left(\mathrm{I}^{-}\right)$ [21]. Consequently, DSSCs with CEs made of PEDOT composited with various types of carbon catalysts often show a high solar conversion efficiency [22-27]. Notably, human hair-derived carbon has rarely been tested as a DSSC CE.

Herein, the hair was carbonized at only $700^{\circ} \mathrm{C}$, and none of harsh chemical treatment was used in any steps in order to retain heterodopant atoms and to lessen the burden of furnace sealing. The synergistic effects of combining carbonized hair at various loadings with PEDOT toward the electrochemical performance and solar conversion efficiency were studied. Our solar conversion efficiency of DSSC with only PEDOT CE is $3.03 \pm 0.09 \%$. Interestingly, mixing carbon at the amount of $0.6 \mathrm{~g}$ with PEDOT significantly increases the efficiency of a DSSC to $6.54 \pm 0.11 \%$, which was not far from those of DSSCs with a Pt CE (7.29 $\pm 0.01 \%)$.

\section{Experimental}

2.1. Preparation of a Working Electrode. Blocking layers were prepared by soaking FTO glass in a boiling $\mathrm{TiCl}_{4} 40 \mathrm{mM}$ at $70^{\circ} \mathrm{C}$ for $30 \mathrm{~min}$. Seven layers of PST-18NR (Catalysts and Chemical Industries Co., Ltd.) and one layer of PST-400 were screen printed on FTO glass. The films were then annealed in an oven at $500^{\circ} \mathrm{C}$ for $1 \mathrm{~h}$ and soaked in a N719 dye solution at a room temperature for $24 \mathrm{~h}$.

2.2. Preparation of a Counter Electrode. Teenager's hair without hair dye from a local barber was thoroughly washed in alcohol and DI water. The hair was carbonized in an argon atmosphere at $700^{\circ} \mathrm{C}$ for $2 \mathrm{~h}$. The carbon was then finely ground and mixed with PEDOT:PSS (Sigma-Aldrich). The different amount of carbonized hair contents were 0.2, 0.4, 0.6 , and $0.8 \mathrm{~g}$ while PEDOT/DI ratio was fixed at $1: 1$. The composites were vigorously stirred and then sonicated for $1 \mathrm{~h}$. Each composite paste was applied on FTO glass with a doctor blade through a Kapton tape mask to define an active area of $0.5 \mathrm{~cm}^{2}$. Then, the films were heated in the oven at $80^{\circ} \mathrm{C}$ for $6 \mathrm{~h}$. A Pt counter electrode was prepared by spin coating Pt solution on FTO glass. Pt solution was prepared by mixing chloroplatinic acid hydrate $\left(\mathrm{H}_{2} \mathrm{PtCl}_{6} \cdot x \mathrm{H}_{2} \mathrm{O}\right.$ $5 \mathrm{mM}$ ) dissolved in DI water $5 \mathrm{~mL}$ with ethyl cellulose $0.2 \mathrm{~g}$ in ethanol $15 \mathrm{~mL}$. Then the film was annealed at $500^{\circ} \mathrm{C}$ for $1.50 \mathrm{~h}$.

2.3. Preparation of an Electrolyte. An electrolyte was prepared by mixing the following chemicals with one another: $0.05 \mathrm{M}$ $\mathrm{I}_{2}, 0.10 \mathrm{M}$ LiI, $0.60 \mathrm{M}$ 1-methyl-3-popylimidazolium iodide (MPI), $0.50 \mathrm{M}$ tetrabutylpyridine (TBP), and $0.0025 \mathrm{M}$ $\mathrm{Li}_{2} \mathrm{CO}_{3}$ in acetonitrile.

2.4. Characterization and Measurements. The surface area of carbonized hair was determined using a BET (BrunnerEmmett-Teller) method. The pore structures of the carbon were investigated by $\mathrm{N}_{2}(77 \mathrm{~K})$ adsorption-desorption measurement with a Bel Sorp mini II adsorption analyzer (Bel, Japan). The samples were degassed at $200^{\circ} \mathrm{C}$ for $3 \mathrm{~h}$. in a vacuum prior to the BET measurement. The morphologies of carbonized hair were characterized by using a scanning electron microscope (SEM, LEO 1450VP, England), a field emission scanning electron microscopy (FESEM, FEI Scios DualBeam, Germany) and a transmission electron microscope (TEM, FEI Tecnai G2, USA). The phase of carbonized hair was investigated with an X-ray diffractometer (XRD, PANanalytical Empyrean, Netherlands) under $\mathrm{Cu} k \alpha$ radiation and a Raman spectroscope (JOBIN YVON HORIBA, T64000) equipped with a $532 \mathrm{~nm}$ solid state laser. Synthetic graphite powder less than $20 \mu \mathrm{m}$ (Sigma-Aldrich) was used as a standard for a 2D-peak reference. The chemical compositions of sample surfaces were investigated using an X-ray photoelectron spectrometer (XPS; AXIS Ultra DLD, Kratos Analytical, UK). The base pressure in the XPS analysis chamber was about $5 \times 10^{-9}$ torr. The monochromatic $\mathrm{Al} \mathrm{K \alpha} 1,2$ source at $1.4 \mathrm{keV}$ was radiated over the spot area of $700 \times 300 \mu \mathrm{m}$. X-ray was maintained at $15 \mathrm{kV}$ and $10 \mathrm{~mA}$ $(150 \mathrm{~W})$. The electrochemical studies were carried out using an electrochemical station (Gamry Instrument Reference 3000, USA). Electrocatalytic activities of all CEs were measured with a cyclic voltammetry $(\mathrm{CV})$ technique in a standard three-electrode setup at a scan rate of $20 \mathrm{mVs}^{-1}$. The impedance characteristics of CEs were determined using electrochemical impedance spectroscopy (EIS) at frequencies ranging from 0.1 to $100 \mathrm{kHz}$ with an AC amplitude of $10 \mathrm{mV}$. The solar conversion efficiency of full DSSC cells were measured using a solar simulator (Class A, PEC-L11, Japan) under a standard illumination of $100 \mathrm{~mW} \mathrm{~cm}^{-2}$.

\section{Results and Discussion}

3.1. Surface and Structure of Carbonized Hair. To understand the microstructure of carbonized hair, nitrogen sorption isotherm was recorded (Figure 1). A carbonized hair sample has type-II adsorption isotherm characteristics typically related to nonporous microstructures [28]. However, the subtle hysteresis loop, related to the minor difference pressure ratio $\left(P / P_{0}\right)$ between a pore filling cycle and an emptying one, should be attributed to the existence of mesopores [28]. This is confirmed by Barrett-Joyner-Halenda (BJH) analysis (Figure 1 inset); however, there are only small 


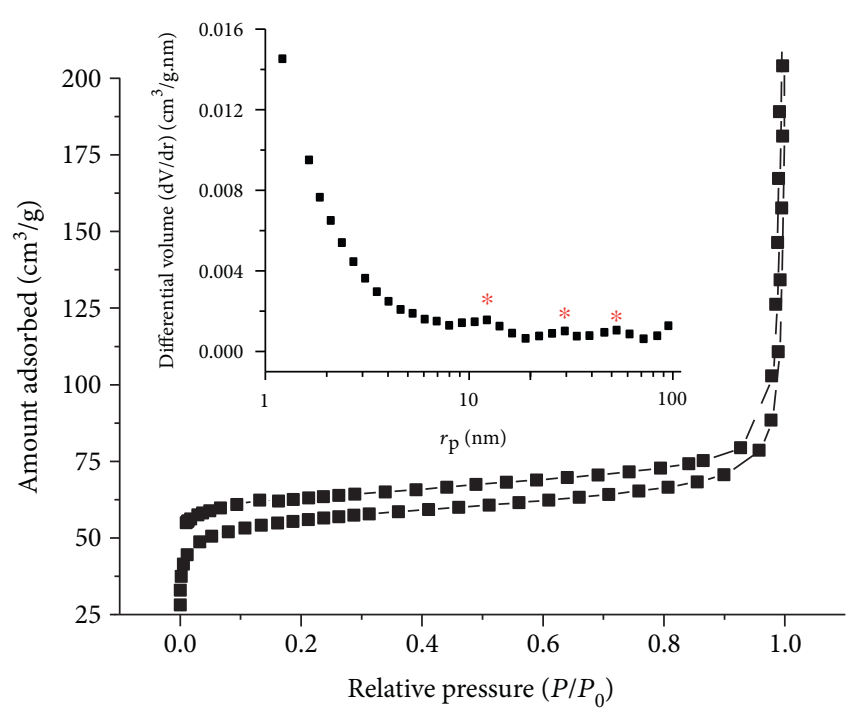

FIGURE 1: The $\mathrm{N}_{2}$ sorption isotherm and inset pore size distribution of carbonized hair.

differential volumic amount of certain pore sizes (noted with asterisk). Since pores are not prevalent, an average surface area of carbonized hair determined from BET technique is mere $187.96 \mathrm{~m}^{2} \mathrm{~g}^{-1}$. This value was not exceptionally high as compared to Sahasrabudhe et al.'s because most carbon flakes were not etched with any chemicals and the carbonization temperature was only $700^{\circ} \mathrm{C}$.

Figure 2 shows the SEM images of ground carbonized hair. Figures 2(a) and 2(b) show the morphology of carbon flakes at low magnification $(1000 \mathrm{x})$ and high magnification $(10 \mathrm{Kx})$, respectively. The sizes of most flakes are generally smaller than $3 \mu \mathrm{m}$. A closer inspection with FESEM at $80 \mathrm{Kx}$ (Figure 2(c)) reveals the rough surface of carbonized hair platelets. Pores are not clearly observed at this magnification. According to TEM imaging (Figure 3(a)), smaller carbon nanoflakes ranging between 100 and $250 \mathrm{~nm}$ are also observed. Pore features are also not clearly resolved in TEM images.

A high-resolution TEM image of carbonized hair (Figure 3(b)) shows the mixture of some graphitic crystallites and an amorphous phase. The lattice fringes of the graphitic phase are approximately $0.33 \mathrm{~nm}$ corresponding to (002) graphitic planes. The selected area electron diffraction (SAED, Figure 3(b) inset) shows ring patterns which belong to (002) and (101) planes without spotted features, implying the presence of sparse short-range order crystallites in the amorphous phase. XRD was used to affirm the existence of crystalline phase in the carbonized hair powder. As shown in Figure 4, the background intensity of the XRD signals is rather high, which should come from the air scattering effect [29]. Moreover, two XRD peaks were observed at $25.5^{\circ}$ and $42.3^{\circ}$. These peaks can be assigned to (002) and (101) planes, respectively [20, 30]. The presence of clear (002) and (101) peaks suggests that the carbonized hair already partially transforms into some turbostratic graphitic structure [30]. Figure 5 shows an example of Raman spectrum which belonged to the carbonized human hair.
Raman curve fittings were carried out using three- and two-peak models to determine the number, position, and area of each of carbon's signature peak. A disorder graphitic structure (D peak) and amorphous (A peak) and graphiticlike (G peak) features were identified in a three-peak model [31]. Note that the A peak was not fitted in the two-peak fitting scheme. Phase identification with Raman analysis is useful because both $G$ peak and D peak are associated with the electrocatalytic reaction. The defective sites on graphitic edges related to $G$ peak could help reduce the charge transfer resistance of the DSSC's CE [32]. Although the electrocatalytic activity occurs mostly at edge planes rather than the basal planes, the basal plane itself could benefit from the electron transfers in the CE. As for the D peak, its area and intensity increase with the increasing disorders in a carbon material, which can be affected by a particle size, a dopant, and others. When carbon particles become smaller, the D peak area and intensity increase. It was shown that a DSSC whose CE was made of smallest carbon black particles $(20 \mathrm{~nm})$ exhibited the highest solar conversion efficiency [33]. This nanocarbon, whose $\mathrm{D}$ peak is large, performs better than the larger ones since it has high surface areas and its disorder sites are electrochemically active in the material. Aside from the size effect, the introduction of heteroatom in carbon normally introduces disorder in a carbon material and consequently raises area ratio of $\mathrm{D}$ peak $\left(I_{\mathrm{D}}\right)$ over $\mathrm{G}$ peak $\left(I_{\mathrm{G}}\right)\left(I_{\mathrm{D}} / I_{\mathrm{G}}\right)$. For example, $I_{\mathrm{D}} / I_{\mathrm{G}}$ of reduced graphene oxide, when doped with nitrogen and phosphorous, increases from 0.94 to 1.15 [34]. The higher $I_{\mathrm{D}} / I_{\mathrm{G}}$ ratio, associating with increasing degree of disorder, offers numerous active sites for electrocatalytic activity [35].

In this study, all peaks were fitted with asymmetric Lorentzian. The peaks are located at $1335.47 \mathrm{~cm}^{-1}$ (D), $1509.37 \mathrm{~cm}^{-1}(\mathrm{~A})$, and $1583.55 \mathrm{~cm}^{-1}(\mathrm{G})$. The $\mathrm{I}_{\mathrm{D}} / \mathrm{I}_{\mathrm{G}}$ ratio determined from the three-peak model is 1.36 . For the twopeak model, the $D$ peak and $G$ peak obtained from asymmetric Lorentzian fitting are situated at $1330.72 \mathrm{~cm}^{-1}$ and $1590.78 \mathrm{~cm}^{-1}$, respectively. From the two-peak model, the $\mathrm{I}_{\mathrm{D}} / \mathrm{I}_{\mathrm{G}}$ ratio is 1.07 which is lower than that of the threepeak model. For our samples, the three-peak model should be more appropriated for fitting because a hidden shoulder peak related to the amorphous phase near $G$ peak is clearly present. Based on the two- and three-peak models, our $I_{\mathrm{D}} / I_{\mathrm{G}}$ is higher than Sahasrabudhe et al.'s work $\left(650-850^{\circ} \mathrm{C}\right)$, meaning our carbon has higher degree of disorder.

Another useful information from Raman analysis is to detect an amorphous phase by considering the secondorder two-phonon mode (2D). The absence of $2 \mathrm{D}$ peak could infer the presence of amorphous phase in the material [36]. From Figure 5(b), 2D peak of graphitic micropowder at $\sim 2703 \mathrm{~cm}^{-1}$ is sharp while that of carbonized hair is very broad and low. This could confirm the presence of amorphous phase as well as some small number of graphitic phase in the carbonized hair sample.

3.2. Composition Analysis. The building blocks of human hair comprise amino acid, keratin, melanin and protein. Therefore, basic elements found in hair are carbon, oxygen, nitrogen, hydrogen, and sulfur $[37,38]$. Generally, burning 


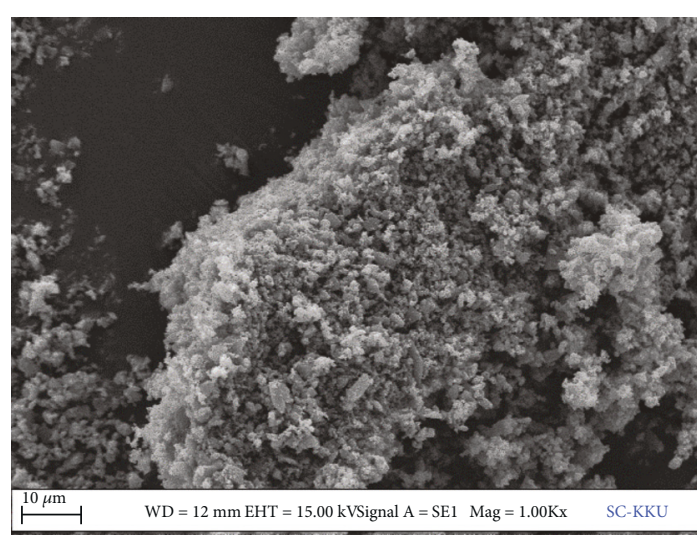

(a)

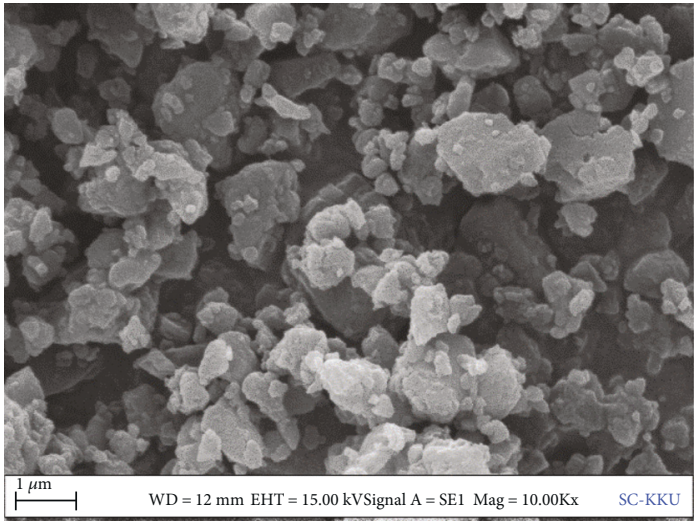

(b)

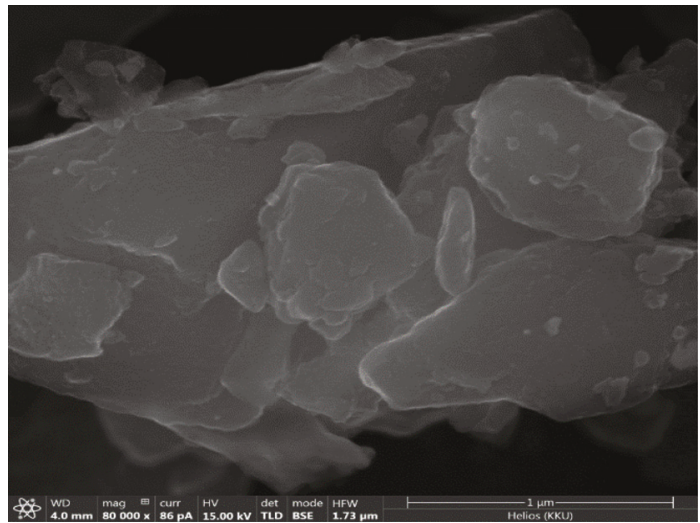

(c)

FIGURE 2: The SEM images of ground carbonized hair. (a) The morphology of carbon flakes at low magnification (1000x), (b) high magnification $(10 \mathrm{Kx})$, and (c) ultrahigh magnification $(80 \mathrm{Kx})$.

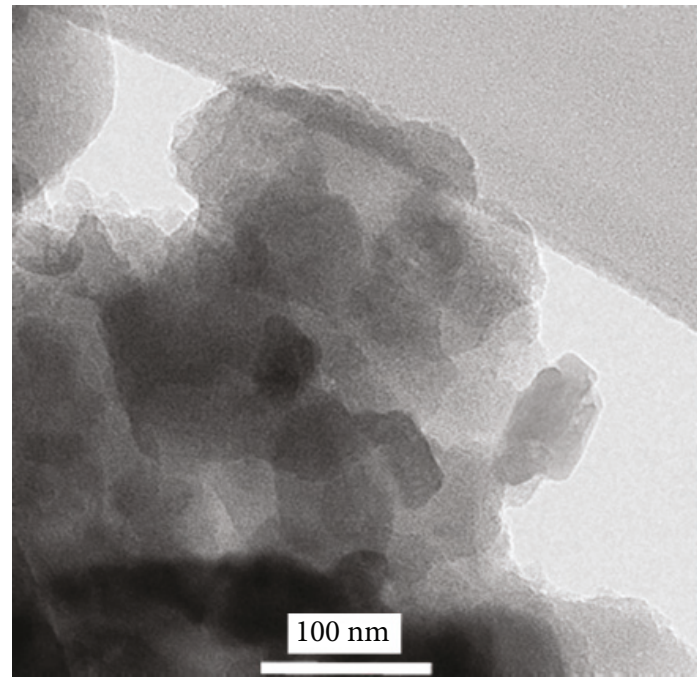

(a)

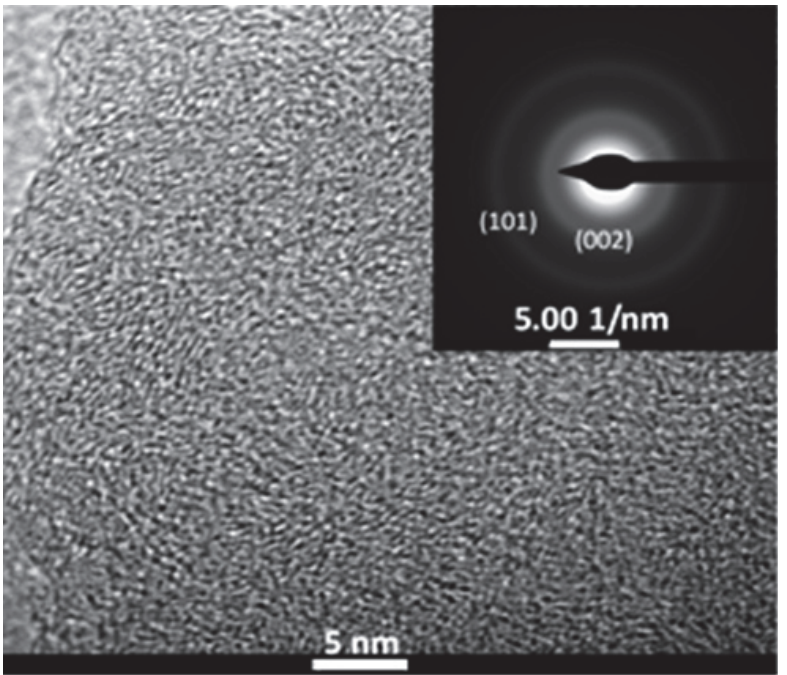

(b)

Figure 3: A TEM image of carbonized hair (a) low resolution, (b) high resolution, and inset SAED.

human hair in a certain oxygen-deficit condition will result in a carbon that contains remaining nitrogen, oxygen, and sulfur if the temperature is not high enough to expel these heteroatoms. Since our carbonization temperature was lower than usual and no harsh chemical was used, it was speculated that many extant heteroatoms were present with the carbon. 


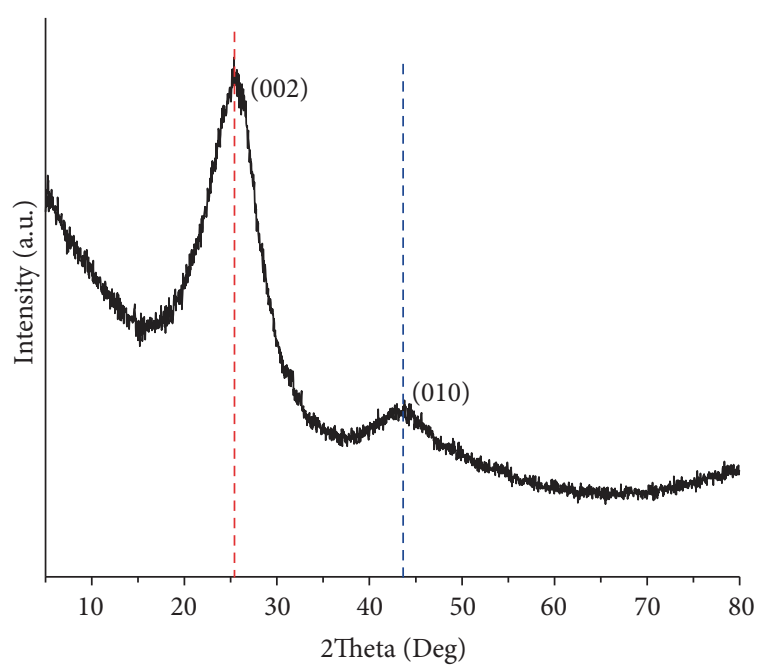

FIGURE 4: An XRD spectrum of carbonized hair.

XPS was used to identify the atomic binding states and the elemental compositions of carbonized hair surface. The XPS results were arranged in Table 1. The XPS peaks shown in Figures 6(a), 6(b), 6(c), 6(d), and 6(e) were indexed following NIST standard and various references [39-41]. The C $1 \mathrm{~s}$ (C-C) peak at $284.9 \mathrm{eV}$ corresponds to $\mathrm{sp}^{2}$ hybridized carbon commonly found in the carbon-based aromatic ring. The $\mathrm{C}$ $1 \mathrm{~s}(\mathrm{C}-\mathrm{C})$ shoulder peak at $286.2 \mathrm{eV}$ reveals the presence of $\mathrm{sp}^{3}$ hybridized carbon. The C-N peak could overlap with the $\mathrm{C}-\mathrm{C}$ peak. Another $\mathrm{C} 1 \mathrm{~s}$ satellite peak at $287.6 \mathrm{eV}$ is related to coincidence sum peak of carbonyl groups $(\mathrm{C}=\mathrm{O})$ and $\mathrm{C}=\mathrm{N}$ while the one located at $288.8 \mathrm{eV}$ corresponds to the ester group $(\mathrm{O}=\mathrm{C}-\mathrm{O})$. The last peak at $290.4 \mathrm{eV}$ is assigned to the carboxylic group $(\mathrm{O}=\mathrm{C}-\mathrm{OH})$. The oxygen-carbon bonds also appear at $530.9 \mathrm{eV}(\mathrm{C}=\mathrm{O}), 532.0 \mathrm{eV}(\mathrm{O}-\mathrm{C}-\mathrm{O}), 533.1 \mathrm{eV}$ $(\mathrm{O}=\mathrm{C}-\mathrm{O})$, and $534.3 \mathrm{eV}$ (amide), respectively. There are three peaks representing nitrogen $\mathrm{N}$ 1s bonds which are located at $398.7 \mathrm{eV}$ (pyridinic), $400.1 \mathrm{eV}$ (pyrrolic), and $401.2 \mathrm{eV}$ (quaternary). Apart from nitrogen, only a small amount of sulfur also appears in the form of thiopenic structures (C-S-C) whose peaks are situated at $163.9 \mathrm{eV}(2 \mathrm{p} \mathrm{3/2})$ and $164.9 \mathrm{eV}(2 \mathrm{p} 1 / 2)$. The presence of $\mathrm{C}-\mathrm{N}$ and $\mathrm{C}=\mathrm{N}$ peaks confirms the doping of nitrogen into the carbon structure. The amount of nitrogen in the our carbon is 9.47 at.\%, which is higher than Si et al.'s report (1-3\%). The amount of oxygen and sulfur in our carbonized hair is 9.98 and 0.15 at.\%, respectively. Such high amount of nitrogen could be of great help to increase the electrocatalytic activity of the carbon catalyst.

3.3. Electrochemical Properties. The electrochemical activities of all samples were investigated by cyclic voltammetry $(\mathrm{CV})$. The CV results were shown in Figures 7(a) and 7(b). All samples have two oxidation peaks and two reduction peaks. The oxidation peaks are related to chemical reactions following (1) and (2) while the reductions reactions correspond to (3) and (4) [42]. It has been accepted that a DSSC performance is also governed by $I_{3}^{-} / I^{-}$redox reaction on the CE side [43]. Therefore, a catalyst on the CE side must be electrochemically active in $I_{3}^{-}$reduction activity. This is justified from the value of cathodic current involving $I_{3}^{-}$reduction $\left(I_{\mathrm{cr}}\right)$, which is located at more negative potential. Higher $\left|I_{c r}\right|$ value indicates better electrocatalytic activity. All the $I_{\mathrm{cr}}$ values are shown in Figure 8. The absolute value of $I_{\text {cr }}$ increases with the increasing carbon up to $0.6 \mathrm{~g}$. Nevertheless, adding carbon beyond this optima results in the slight decrease in $\left|I_{\text {cr }}\right|$. This could be due to the reduction of catalytic activity induced by agglomerations that partially block some active sites. Based on $\mathrm{CV}$ results, $\mathrm{C}_{0.6} \mathrm{P}$ should have the best electrocatalytic activity among $\mathrm{C}_{x} \mathrm{P}$. Nonetheless, $I_{\text {cr }}$ value $\left(2.53 \times 10^{-4} \mathrm{~mA}\right)$ of $\mathrm{C}_{0.6} \mathrm{P}$ is still lower than that of $\mathrm{Pt}\left(4.77 \times 10^{-4} \mathrm{~mA}\right)$, implying that $\mathrm{Pt}$ is better than $\mathrm{C}_{0.6} \mathrm{P}$ regarding the $I_{3}^{-}$reduction capability.

$$
\begin{array}{cc}
\text { Oxidation 1 } & 3 I^{-}-2 e^{-} \rightarrow I_{3}^{-} \\
\text {Oxidation 2 } & 2 I_{3}^{-}-2 e^{-} \rightarrow I_{2} \\
\text { Reduction 1 } & I_{3}^{-}+2 e^{-} \rightarrow 3 I^{-} \\
\text {Reduction 2 } & 3 I_{2}+2 e^{-} \rightarrow 2 I_{3}^{-}
\end{array}
$$

Apart from a CV technique, impedance measurements to determine a series resistance $\left(R_{\mathrm{s}}\right)$, a transport resistance in PEDOT and carbon layer $\left(R_{\text {trp }}\right)$, and a charge transfer resistance at CE surface $\left(R_{\mathrm{ct}}\right)$ were performed [44]. The electrochemical impedance spectra (EIS) of symmetric CE cells were shown in Figures 9(a), 9(b), 9(c), and 9(d). All the resistance values (Table 2 ) were derived by fitting the impedance data with an equivalent circuit [44]. $R_{\mathrm{s}}$ is a combination of series resistances from FTO glass, test wires, and ohmic contacts between FTO glass and an electrocatalytic layer. $R_{\mathrm{s}}$ is related to the $x$-axis intercept of the 1st semicircle at high frequency. The $R_{\text {trp }}$ is a real part within the 1st semicircle of PEDOT and $\mathrm{C}_{x} \mathrm{P}$ except for Pt which has no semicircle related to the $R_{\mathrm{trp}}$. As for the $R_{\mathrm{ct}}$ value, $R_{\mathrm{ct}}$ is a real part within the 2nd semicircle of PEDOT and the composites; however, in the case of $\mathrm{Pt}$, the $R_{\mathrm{ct}}$ was determined from a high frequency peak (1st semicircle) [12, 45, 46]. The reason that Pt (Figure 9(b) (inset)) does not have $R_{\text {trp }}$-related semicircle is because $\mathrm{Pt}$ is highly conductive.

Furthermore, Pt has the lowest $R_{\mathrm{s}}(13.48 \Omega)$ among all samples, which also implies that spinning coating induces good adhesion between the Pt film and the FTO substrate. The $R_{\mathrm{s}}$ of PEDOT is $16.17 \Omega$ while the highest one belonged to $\mathrm{C}_{0.8} \mathrm{P}(17.13 \Omega)$. The additions of carbon from 0.2 to $0.6 \mathrm{~g}$ into PEDOT only slightly increase the $R_{\mathrm{s}}$ of PEDOT. This should be due to the slightly poorer adhesion between the film and FTO glass and the incremental series resistances when more carbon contents were added.

In the case of $R_{\text {trp }}$, PEDOT has the largest $R_{\text {trp }}$ value $(2.28 \Omega)$. Adding carbon at the amount of 0.2 and $0.4 \mathrm{~g}$ reduces $R_{\text {trp }}$ to $1.43 \Omega$ and $0.84 \Omega$, respectively. This is because carbon increases the conducting pathways in the composite. Additional carbon loadings $(0.6$ and $0.8 \mathrm{~g})$ lead to slight increasing of $R_{\text {trp }}$ (1.14 and 2.25 $\Omega$ ). The reason for this is that even though more carbons could further reduce the trp resistance, counteraction to such effect might come from accumulative carbon's resistances. 


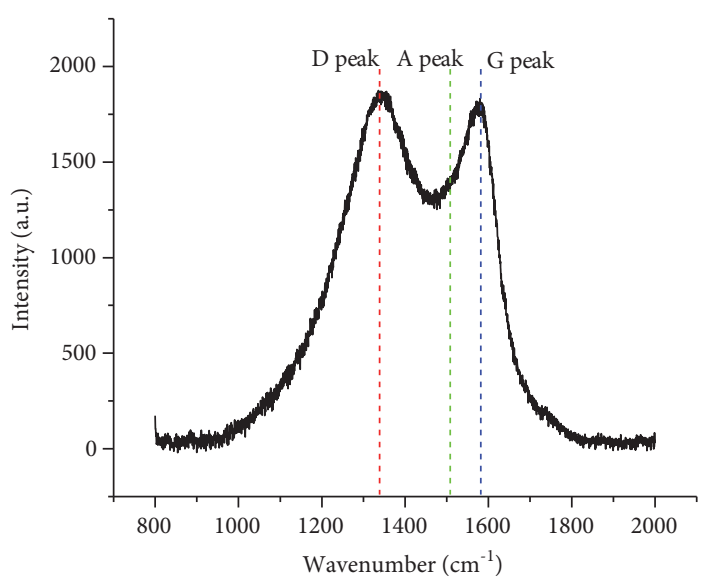

(a)

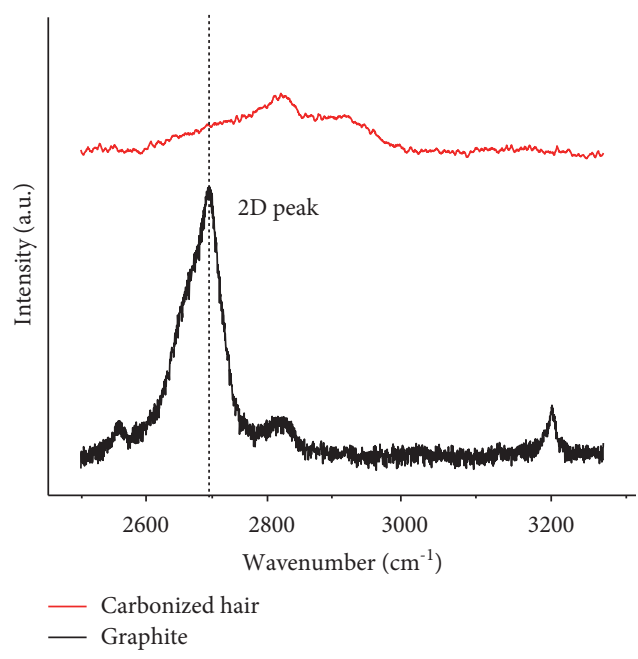

(b)

Figure 5: A Raman spectrum of (a) carbonized hair (from 800 to $2000 \mathrm{~cm}^{-1}$ ) and (b) carbonized hair and graphite (from 2500 to $3200 \mathrm{~cm}^{-1}$ ).

TABLE 1: The peak assignment and elemental composition derived from XPS spectra.

\begin{tabular}{|c|c|c|c|c|}
\hline Peak & $\begin{array}{c}\text { Binding } \\
\text { energy }(\mathrm{eV})\end{array}$ & Assignment & $\begin{array}{c}\text { Element } \\
\text { composition } \\
\text { (at.\%) }\end{array}$ & $\begin{array}{l}\text { Fraction of } \\
\text { species (\%) }\end{array}$ \\
\hline \multirow{5}{*}{ C $1 \mathrm{~s}$} & 284.9 & $\mathrm{Sp}^{2} \mathrm{C}-\mathrm{C}$ & \multirow{5}{*}{80.22} & 58.3 \\
\hline & 286.2 & $\mathrm{Sp}^{3} \mathrm{C}-\mathrm{C}, \mathrm{C}-\mathrm{N}$ & & 23.1 \\
\hline & 287.6 & $-\mathrm{C}=\mathrm{O}, \mathrm{C}=\mathrm{N}$ & & 8.8 \\
\hline & 288.8 & $\mathrm{O}=\mathrm{C}-\mathrm{O}$ & & 6.9 \\
\hline & 290.4 & $\mathrm{O}=\mathrm{C}-\mathrm{OH}$ & & 2.9 \\
\hline \multirow{4}{*}{ O $1 \mathrm{~s}$} & 530.9 & $\mathrm{C}=\mathrm{O}$ & \multirow{4}{*}{9.98} & 30.0 \\
\hline & 532.0 & $\mathrm{O}-\mathrm{C}-\mathrm{O}$ & & 34.4 \\
\hline & 533.1 & $\mathrm{O}-\mathrm{C}=\mathrm{O}$ & & 29.1 \\
\hline & 534.4 & Amide & & 6.5 \\
\hline \multirow{3}{*}{$\mathrm{N} 1 \mathrm{~s}$} & 398.7 & $\begin{array}{l}\text { Pyridinic } \\
\text { N (N-6) }\end{array}$ & \multirow{3}{*}{9.47} & 43.4 \\
\hline & 400.1 & $\begin{array}{l}\text { Pyrrolic } \\
\text { N (N-5) }\end{array}$ & & 36.8 \\
\hline & 401.2 & $\begin{array}{l}\text { Quaternary } \\
\mathrm{N}(\mathrm{N}-\mathrm{Q})\end{array}$ & & 19.8 \\
\hline \multirow{2}{*}{$S 2 p$} & 163.9 & $\begin{array}{l}\text { Thiophenic } \\
(\mathrm{C}-\mathrm{S}-\mathrm{C}) 3 / 2\end{array}$ & \multirow[t]{2}{*}{0.15} & 57.4 \\
\hline & 164.9 & $\begin{array}{l}\text { Thiophenic } \\
\text { (C-S-C) } 1 / 2\end{array}$ & & 42.6 \\
\hline
\end{tabular}

The $R_{\mathrm{ct}}$ is the resistance at the interface between the CE surface and the electrolyte. Low $R_{\mathrm{ct}}$ denotes the high electrocatalytic activity of CE catalyst. PEDOT has the highest $R_{\mathrm{ct}}$ $(152.08 \Omega$ ) among all samples. For $0.2-0.6 \mathrm{~g}$ of carbon contents, the $R_{\text {ct }}$ of the $\mathrm{C}_{x} \mathrm{P}$ is decreasing with increasing amount of carbon, suggesting the enhancement in electrocatalytic activity. This is related to the rise of electrochemical actives sites for $I_{3}^{-}$reduction, which is attributed to increasing in carbon catalysts and the PEDOT's surface areas as well as the ease of electrolyte access.
The lowest $R_{\mathrm{ct}}$ among the $\mathrm{C}_{x} \mathrm{P}$ is realized for $\mathrm{C}_{0.6} \mathrm{P}$ $(7.11 \Omega)$. Yet, if the carbon content is $0.8 \mathrm{~g}$, the $R_{\mathrm{ct}}$ escalates to $29.98 \Omega$. This might correspond to carbon agglomeration at high carbon loading and consequently leads to the decline in the active area of carbon and PEDOT. Note that the $\mathrm{R}_{\mathrm{ct}}$ of $\mathrm{C}_{0.8} \mathrm{P}(29.98 \Omega)$ is still lower than that of $\mathrm{C}_{0.4} \mathrm{P}(54.39 \Omega)$. Compared with $\mathrm{Pt}$, the $R_{\mathrm{ct}}$ of $\mathrm{C}_{0.6} \mathrm{P}$ is higher than $\mathrm{Pt}$ 's $(4.58 \Omega)$. The trend of $R_{c t}$ with varied carbon amount is reasonable because it goes inversely with $\left|I_{\mathrm{cr}}\right|$ [47].

The summation of resistances $\left(R_{\mathrm{s}}+R_{\mathrm{trp}}+R_{\mathrm{ct}}\right)$ is shown in Table 2. These overall resistances impede the electrochemical activity and have negative effect toward solar efficiency. $\mathrm{C}_{0.6} \mathrm{P}$ has the lowest overall resistance meaning that it should have the highest electrocatalytic activity among $\mathrm{C}_{x} \mathrm{P}$. However, its electrocatalytic activity is lower than that of $\mathrm{Pt}$.

3.4. Solar Efficiency. The main parameters affecting a solar efficiency are an open-circuit voltage $\left(V_{\mathrm{oc}}\right)$, a fill factor $(\mathrm{FF})$, and a short-circuit current density $\left(J_{\mathrm{sc}}\right)$. To gain high energy conversion efficiency, these three parameters must be as high as possible. The $J-V$ characteristics of selected samples of a DSSC with $\mathrm{C}_{x} \mathrm{P}$ CE ( $\mathrm{C}_{x} \mathrm{P}$ DSSC) and a DSSC with Pt CE (Pt DSSC) were shown in Figure 10. All the photovoltaic parameters were summarized in Table 2 . The $V_{\mathrm{oc}}$ is expressed as the difference between the $\mathrm{TiO}_{2}$ 's Fermi level and the electronic energy of $I_{3}^{-} / I^{-}$redox couple [48]. Therefore, the $V_{\mathrm{oc}}$, mostly depends on the $\mathrm{TiO}_{2}$, a dye, and an electrolyte quality.

In this work, $V_{\text {oc }}$ values of all $\mathrm{C}_{x} \mathrm{P}$ DSSCs fall within $0.75-0.76 \mathrm{~V}$, which are also close of Pt DSSC $(0.74 \mathrm{~V})$. This corresponds to the reproducible fabrication of the $\mathrm{TiO}_{2}$ photoanode films. As for the FF factor, this parameter depends on the whole processes essential for the operation of DSSC. On the CE side, such processes include $I_{3}^{-}$supply, $I_{3}^{-}$to $I^{-}$conversion activity, and $I^{-}$availability [49]. Therefore, the electrochemical activity and the resistances of CEs are useful for the interpretation of relationship between carbon content and the FF value. The fill factor 

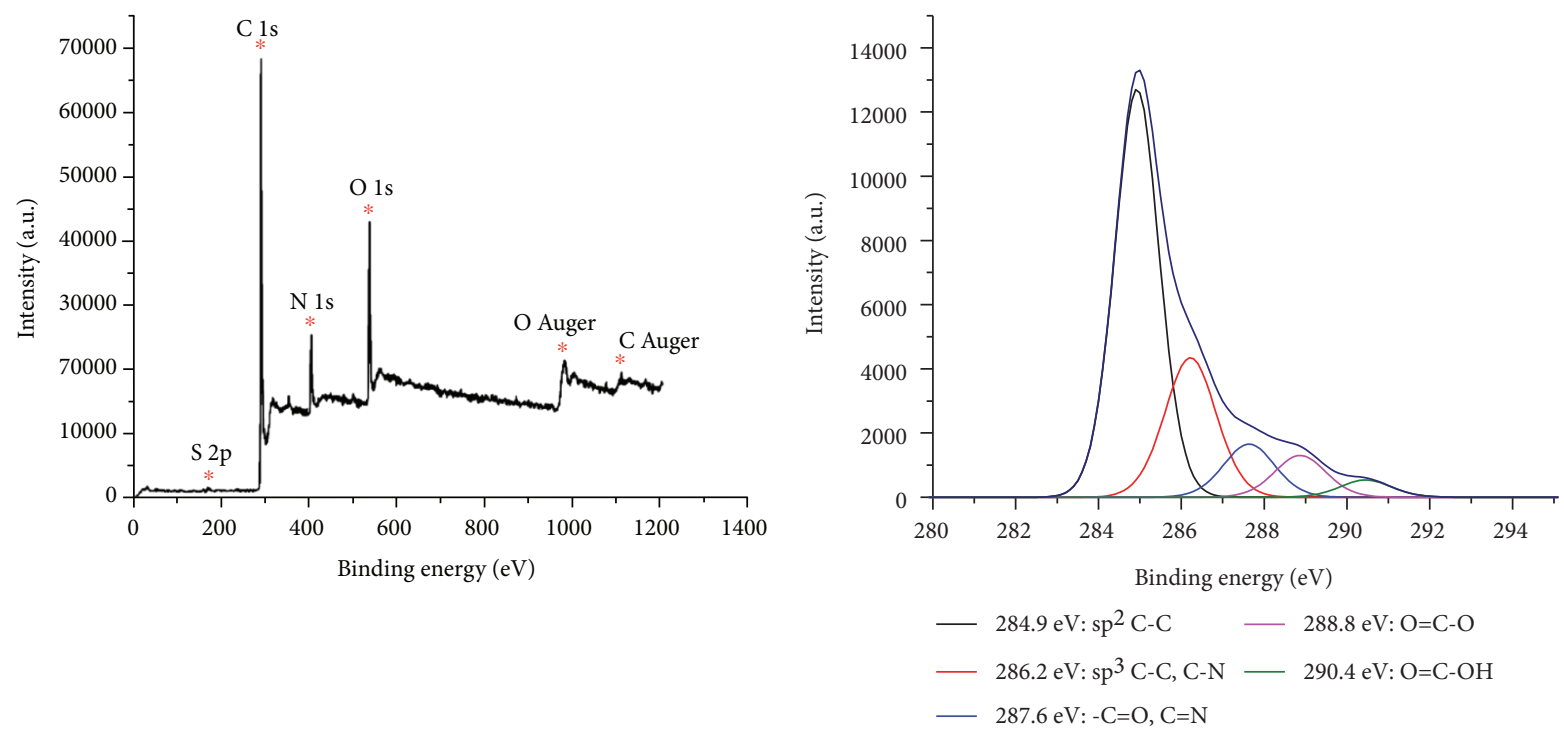

(a)

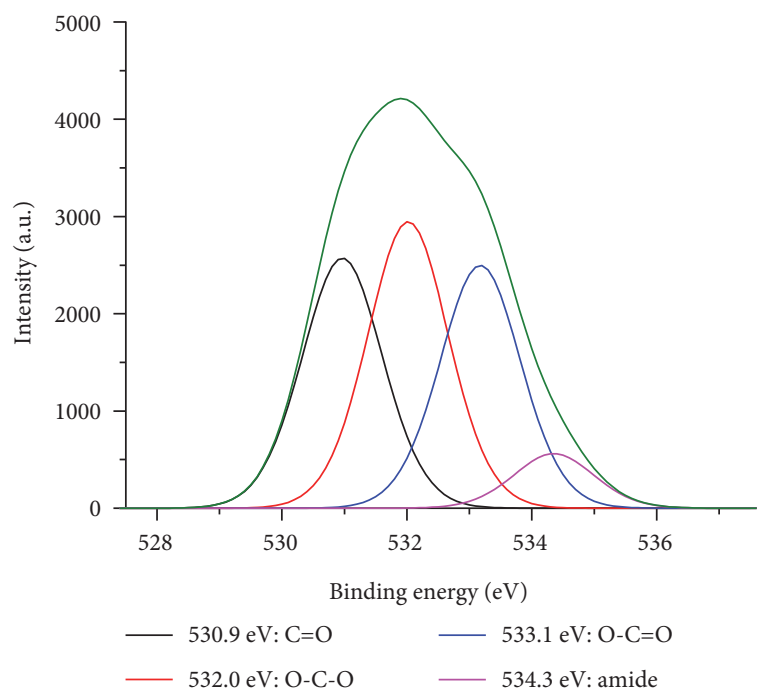

(b)

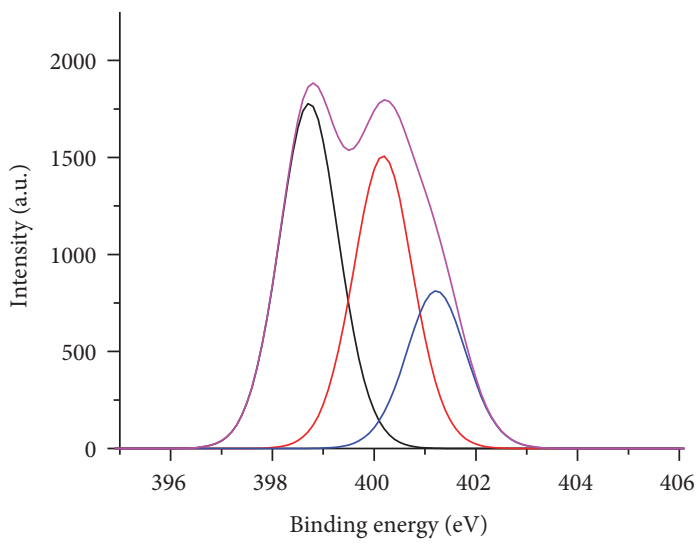

$$
\begin{aligned}
& \text { — } 398.7 \mathrm{eV} \text { : pyridinic } \mathrm{N}(\mathrm{N}-6) \\
& \text { — } 400.1 \mathrm{eV} \text { : pyrrolic N (N-5) } \\
& \text { — } 401.2 \mathrm{eV} \text { : quaternary N (N-Q) }
\end{aligned}
$$

(c)

(d)

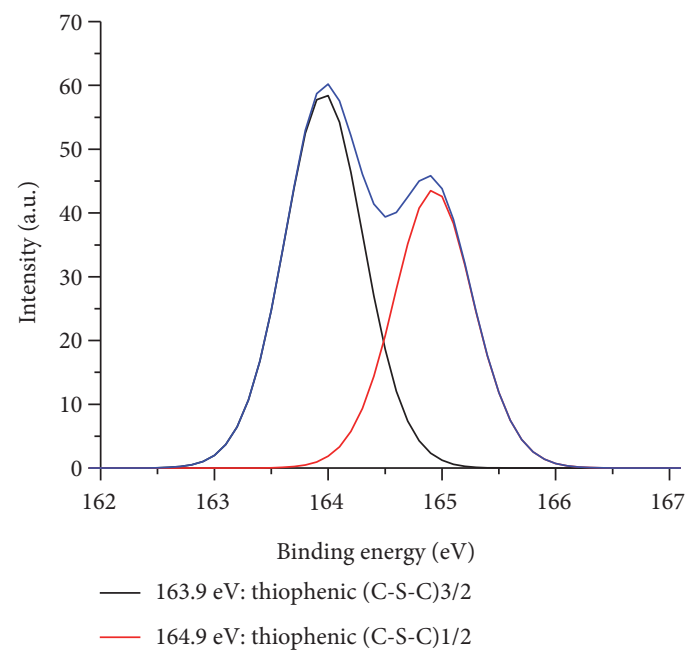

(e)

FIGURE 6: XPS spectra of carbonized hair. (a) XPS survey spectrum, (b) C 1s, (c) O 1s, (d) N 1s, and (e) S 2p. 


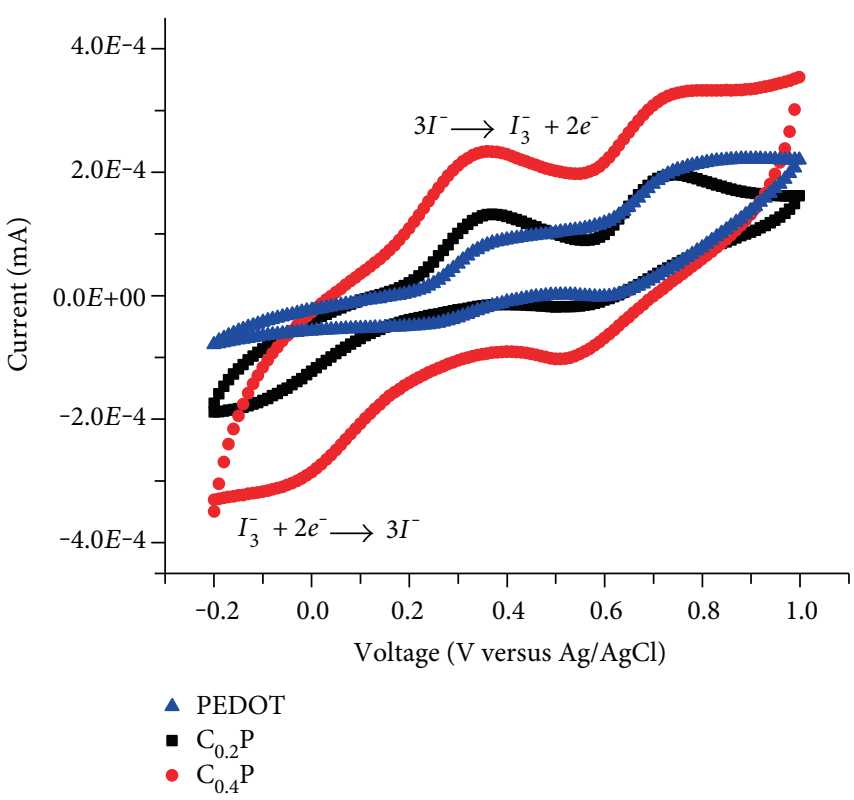

(a)

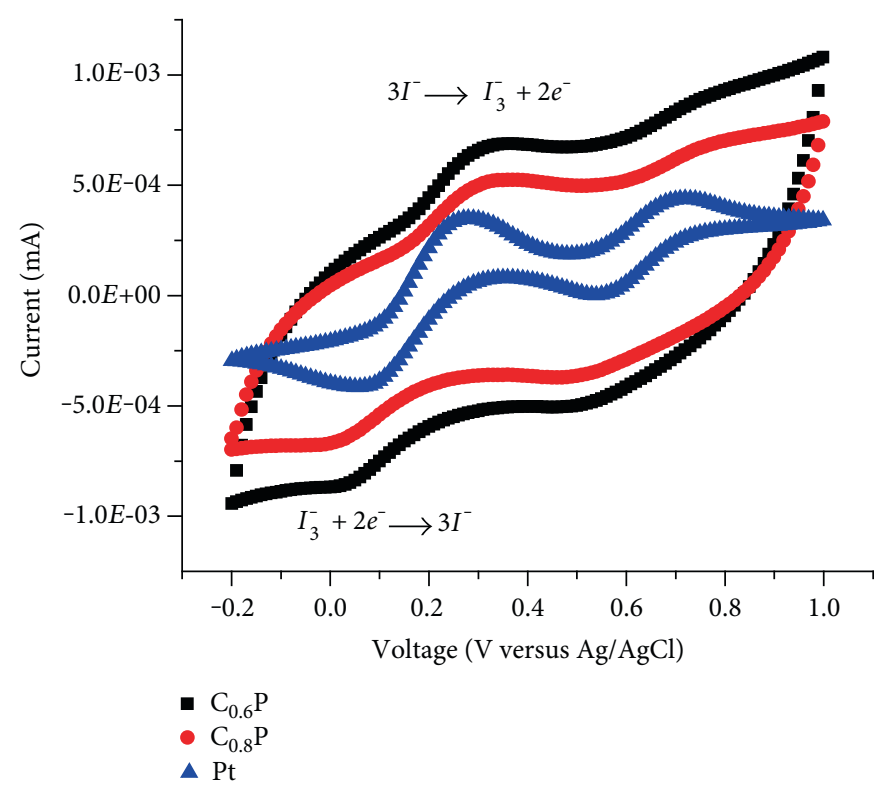

(b)

Figure 7: CV results of counter electrodes. (a) $\mathrm{C}_{0.2} \mathrm{P}, \mathrm{C}_{0.4} \mathrm{P}$, and PEDOT. (b) $\mathrm{C}_{0.6} \mathrm{P}, \mathrm{C}_{0.8} \mathrm{P}$, and Pt.

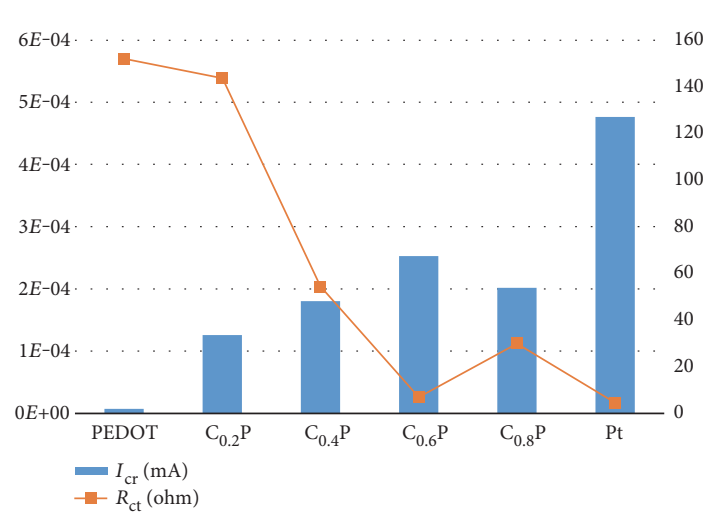

FIGURE 8: The relationship between $I_{\mathrm{cr}}$ and $R_{\mathrm{ct}}$.

of PEDOT DSSCs is only $0.31 \pm 0.01$. PEDOT DSSC has low FF because PEDOT has the poorest electrocatalytic activity as verified from $\mathrm{CV}$ results. The $\mathrm{FF}$ value rises with the increasing carbon amount $(0.2$ to $0.6 \mathrm{~g})$ due to increasing catalytic sites and reduction of total resistances. Nevertheless, when $0.8 \mathrm{~g}$ of carbon is added, the FF does not significantly increase as compared to that of $\mathrm{C}_{0.6} \mathrm{P}$ DSSC due to the increase in the overall resistances (Table 2). Among $\mathrm{C}_{x} \mathrm{P}$ DSSCs, the high FF value of 0.58 \pm 0.01 is obtained for $\mathrm{C}_{0.6} \mathrm{P}$ DSSC and $\mathrm{C}_{0.8} \mathrm{P}$ DSSC. However, their values are lower than that of Pt DSSC (0.63) because Pt's total resistance is the lowest.

The $J_{\mathrm{sc}}$ is a photocurrent density measured without any external loads under a short-circuit condition. Similar to $\mathrm{FF}, J_{\mathrm{sc}}$ value is dictated by electrocatalytic activity and a total resistance. That is, high electrocatalytic activity and low total resistance are required to ease electrochemical processes of $\mathrm{CE}$ side and so guaranteeing a high $J_{\mathrm{sc}}$ value [49]. With increasing carbon content from 0.2 to $0.4 \mathrm{~g}$, the $J_{\mathrm{sc}}$ increases and reaches its maximum for carbon content of $0.6 \mathrm{~g}$ $\left(14.85 \pm 0.03 \mathrm{~mA} \mathrm{~cm}^{-2}\right)$. However, $J_{\mathrm{sc}}$ decreases with increasing carbon content to $0.8 \mathrm{~g}\left(14.52 \pm 0.05 \mathrm{~mA} \mathrm{~cm}^{-2}\right)$ as electrocatalytic activity decrease for excessive carbon loading. This is explained by the sudden increase of total resistance of symmetric $\mathrm{C}_{0.8} \mathrm{P}$ DSSC as compared to that of $\mathrm{C}_{0.6} \mathrm{P}$ DSSC. The maximum $J_{\mathrm{sc}}$ belonged to Pt DSSC $\left(15.64 \pm 0.02 \mathrm{~mA} \mathrm{~cm}^{-2}\right)$ as Pt DSSC has the lowest total resistance.

Among all samples, PEDOT has the lowest efficiency $(3.03 \pm 0.09 \%)$ due to its low FF and $J_{\text {sc }}$ values. Combining carbonized hair with PEDOT provides the synergistic catalytic effect for $I_{3}^{-}$reduction. The $\mathrm{FF}$ and $J_{\mathrm{sc}}$ values are increasing with the increasing carbon loadings from 0.2 to $0.6 \mathrm{~g}$. Accordingly, the efficiency keeps increasing until the maximum efficiency is reached at $6.54 \pm 0.11 \%$ for $\mathrm{C}_{0.6} \mathrm{P}$ DSSC. Nonetheless, too high carbon loading $(0.8 \mathrm{~g})$ results in the reduction of DSSC's efficiency $(6.31 \pm 0.11 \%)$. The efficiency of Pt DSSC $(7.29 \pm 0.01 \%)$ is higher than that of $\mathrm{C}_{0.6} \mathrm{P}$ DSSC due to the higher $\mathrm{FF}$ and $J_{\mathrm{sc}}$ values achieved in Pt DSSC.

\section{Conclusion}

Composite films made of PEDOT and nonactivated carbonized hair were tested as DSSC CEs. Though the carbon does not have exceptionally large specific surface area $\left(187.96 \mathrm{~m}^{2} \mathrm{~g}^{-1}\right)$, it is effective enough for electrocatalytic reduction of $I_{3}^{-}$, which could be due to the contribution of nitrogen dopants (up to 9.47 at.\%) and from graphitic- 


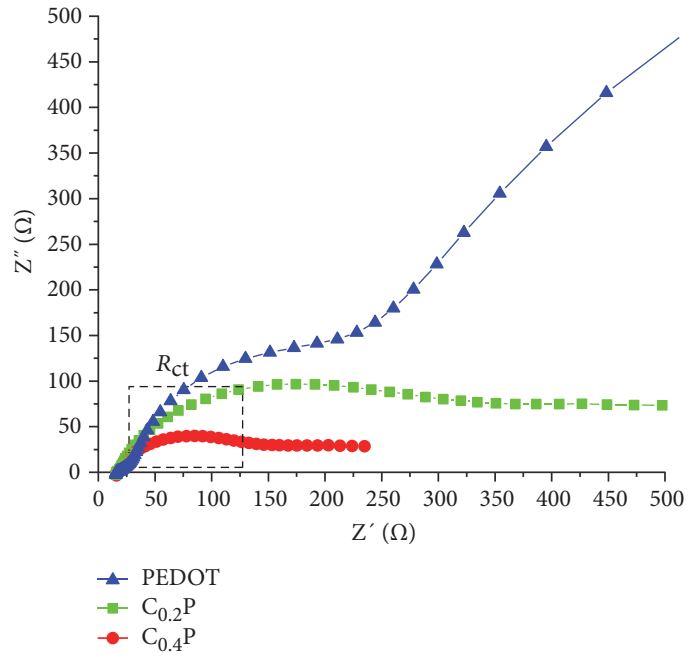

(a)

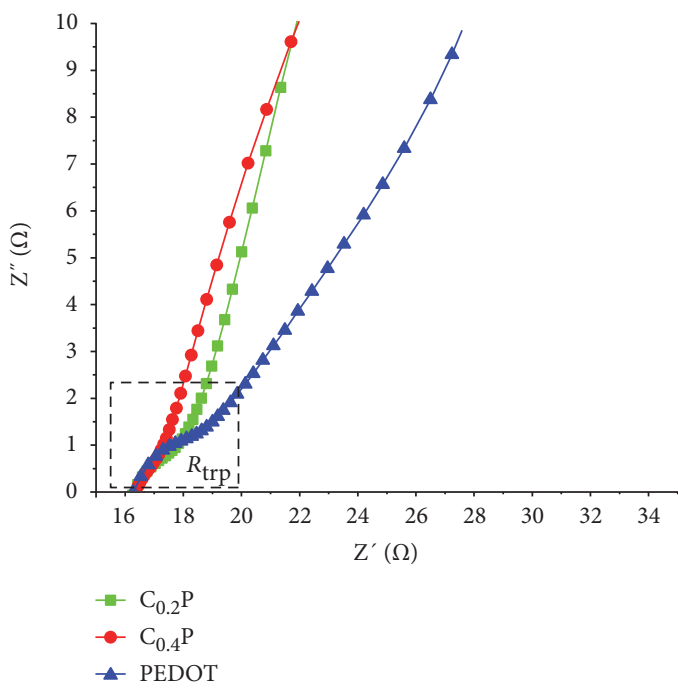

(c)

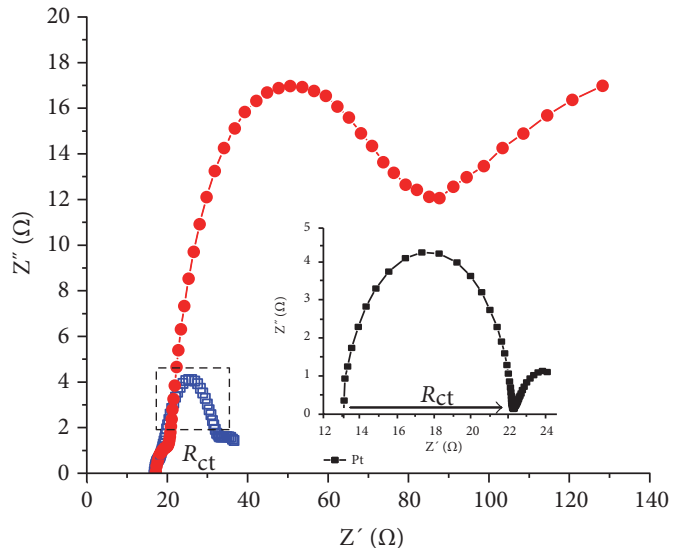

$\rightarrow-\mathrm{C}_{0.6} \mathrm{P}$
$\rightarrow-\mathrm{C}_{0.8} \mathrm{P}$

(b)

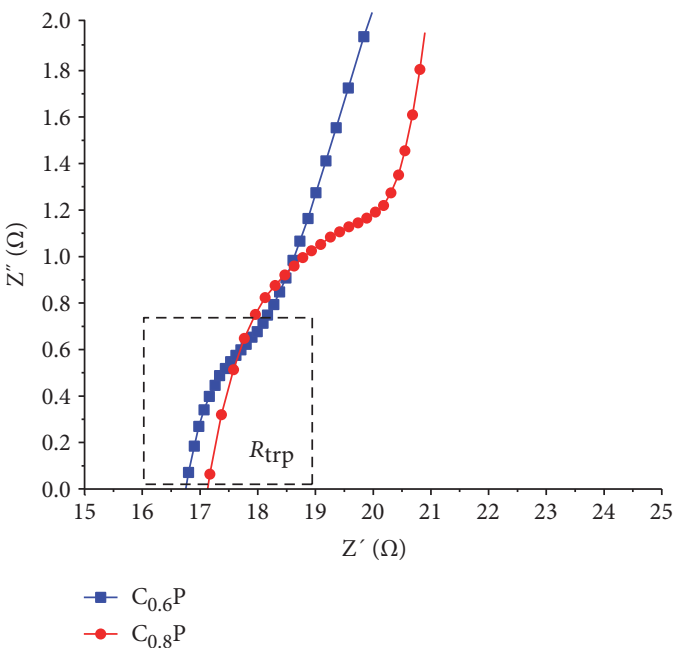

(d)

FIgure 9: Impedance spectra of counter electrodes. (a) $\mathrm{C}_{0.2} \mathrm{P}, \mathrm{C}_{0.4} \mathrm{P}$, and PEDOT; (b) $\mathrm{C}_{0.6} \mathrm{P}$ and $\mathrm{C}_{0.8} \mathrm{P}$; and inset $\mathrm{Pt}$ (c) zoom-in detail of 9 (a) and (d) zoom-in detail of 9 (b).

TABLE 2: Photovoltaic parameters and EIS resistances of different counter electrodes.

\begin{tabular}{|c|c|c|c|c|c|c|c|c|}
\hline \multirow{2}{*}{ Counter electrodes } & \multicolumn{4}{|c|}{ Photovoltaic parameters } & \multicolumn{4}{|c|}{ Electrochemical impedance spectroscopy } \\
\hline & $J_{\mathrm{sc}}\left(\mathrm{mA} \mathrm{cm}^{-2}\right)$ & $V_{\mathrm{oc}}(\mathrm{V})$ & FF & $\eta(\%)$ & $R_{\mathrm{s}}(\Omega)$ & $R_{\operatorname{trp}}(\Omega)$ & $R_{\mathrm{ct}}(\Omega)$ & $R_{\text {Total }}(\Omega)$ \\
\hline PEDOT & $13.03 \pm 0.05$ & $0.75 \pm 0.0028$ & $0.31 \pm 0.01$ & $3.03 \pm 0.09$ & 16.17 & 2.28 & 152.08 & 170.53 \\
\hline $\mathrm{C}_{0.2} \mathrm{P}$ & $13.54 \pm 0.03$ & $0.76 \pm 0.0019$ & $0.46 \pm 0.00$ & $4.73 \pm 0.02$ & 16.35 & 1.43 & 143.65 & 161.43 \\
\hline $\mathrm{C}_{0.4} \mathrm{P}$ & $14.48 \pm 0.04$ & $0.76 \pm 0.0025$ & $0.55 \pm 0.02$ & $6.05 \pm 0.22$ & 16.49 & 0.84 & 54.39 & 71.72 \\
\hline $\mathrm{C}_{0.6} \mathrm{P}$ & $14.85 \pm 0.03$ & $0.76 \pm 0.0018$ & $0.58 \pm 0.01$ & $6.54 \pm 0.11$ & 16.76 & 1.14 & 7.11 & 25.01 \\
\hline $\mathrm{C}_{0.8} \mathrm{P}$ & $14.52 \pm 0.05$ & $0.75 \pm 0.0029$ & $0.58 \pm 0.01$ & $6.31 \pm 0.11$ & 17.13 & 2.25 & 29.98 & 49.36 \\
\hline $\mathrm{Pt}$ & $15.64 \pm 0.02$ & $0.74 \pm 0.0010$ & $0.63 \pm 0.00$ & $7.29 \pm 0.01$ & 13.48 & - & 4.58 & 18.06 \\
\hline
\end{tabular}

like carbons as well as the disordered types. Without carbon, a PEDOT DSSC has the lowest efficiency $(3.03 \pm 0.09 \%)$ due to its low FF and $J_{\mathrm{sc}}$. Compositing carbonized hair with
PEDOT helps improve FF and $J_{\text {sc }}$ values of DSSCs. The maximum efficiency of $6.54 \pm 0.11 \%$ was achieved for $\mathrm{C}_{0.6} \mathrm{P}$ DSSC. Though the efficiency of $\mathrm{C}_{0.6} \mathrm{P}$ DSSC is lower than 


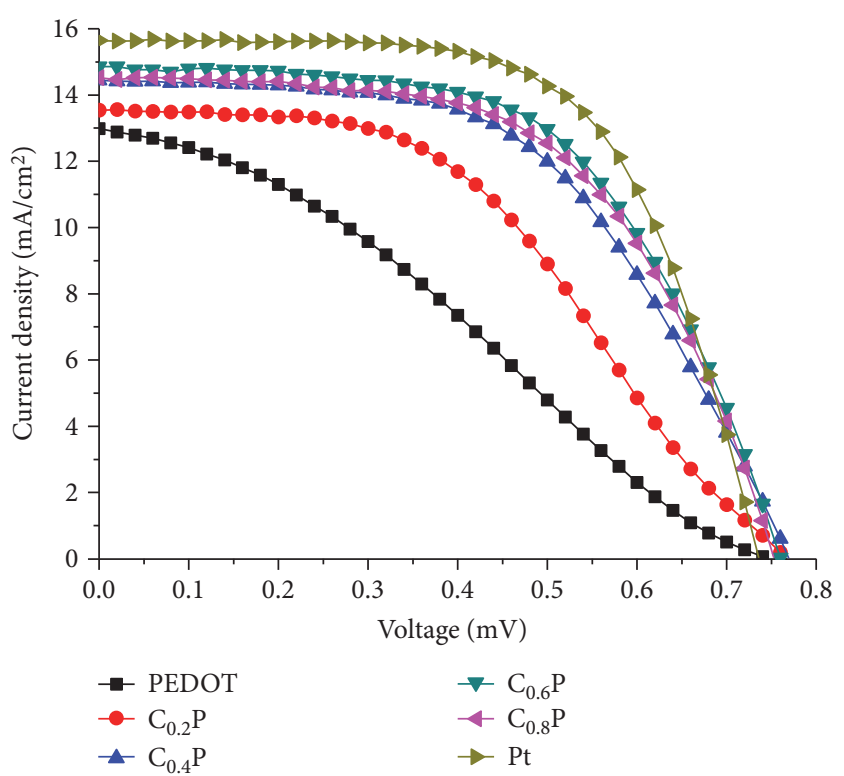

Figure 10: $J$ - $V$ curves of counter electrodes.

Pt DSSC's $(7.29 \pm 0.01 \%)$ due to its lower FF and $J_{s c}$, the carbon catalyst proposed here is still interesting for a DSSC application because our preparation steps involve no harsh chemical. Moreover, the selected carbonization temperature herein is only $700^{\circ} \mathrm{C}$.

\section{Conflicts of Interest}

The authors declare that they have no conflicts of interest.

\section{Acknowledgments}

This work was supported by the Science Achievement Scholarship of Thailand (SAST); the Nanotechnology Center (NANOTEC), NSTDA, Ministry of Science and Technology, Thailand, through its program of Center of Excellence Network, Center for Alternative Energy Research and Development, Khon Kaen University; the Higher Education Research Promotion and National Research University Project of Thailand, Office of the Higher Education Commission, through the Advanced Functional Materials Cluster of Khon Kaen University; the Integrated Nanotechnology Research Center, Khon Kaen University, Thailand; and Thailand Center of Excellence in Physics, Commission on Higher Education.

\section{References}

[1] S. Mathew, A. Yella, P. Gao et al., "Dye-sensitized solar cells with $13 \%$ efficiency achieved through the molecular engineering of porphyrin sensitizers," Nature Chemistry, vol. 6, no. 3, pp. 242-247, 2014.

[2] S. H. Park, B. K. Kim, and W. J. Lee, "Electrospun activated carbon nanofibers with hollow core/highly mesoporous shell structure as counter electrodes for dye-sensitized solar cells," Journal of Power Sources, vol. 239, pp. 122-127, 2013.

[3] S. H. Park, Y. H. Cho, M. Choi et al., "Nickel-nitride-coated nickel foam as a counter electrode for dye-sensitized solar cells," Surface \& Coatings Technology, vol. 259, pp. 560569, 2014.

[4] F. Yao, P. Sun, X. Sun et al., "One-step hydrothermal synthesis of $\mathrm{ZnS}-\mathrm{CoS}$ microcomposite as low cost counter electrode for dye-sensitized solar cells," Applied Surface Science, vol. 363, pp. 459-465, 2016.

[5] P. Vijayakumar, M. Senthil Pandian, S. P. Lim et al., "Facile synthesis of tungsten carbide nanorods and its application as counter electrode in dye sensitized solar cells," Materials Science in Semiconductor Processing, vol. 39, pp. 292-299, 2015.

[6] H. Kim, G. Veerappan, and J. H. Park, "Conducting polymer coated non-woven graphite fiber film for dye-sensitized solar cells: superior Pt- and FTO-free counter electrodes," Electrochimica Acta, vol. 137, pp. 164-168, 2014.

[7] W. Zheng, T. Qi, Y. C. Zhang, H. Y. Shi, and J. Q. Tianqing, "Fabrication and characterization of a multi-walled carbon nanotube-based counter electrode for dye-sensitized solar cells," New Carbon Materials, vol. 30, no. 5, pp. 391-396, 2015.

[8] I. A. Sahito, K. C. Sun, A. A. Arbab, M. B. Qadir, and S. H. Jeong, "Graphene coated cotton fabric as textile structured counter electrode for DSSC," Electrochimica Acta, vol. 173, pp. 164-171, 2015.

[9] L. Qiu, H. Zhang, W. Wanga, Y. Chena, and R. Wang, "Effects of hydrazine hydrate treatment on the performance of reduced graphene oxide film as counter electrode in dye-sensitized solar cells," Applied Surface Science, vol. 319, pp. 339-343, 2014.

[10] I. Y. Y. Bu and J. Zheng, "A new type of counter electrode for dye sensitized solar cells based on solution processed $\mathrm{SnO}_{2}$ and activated carbon," Materials Science in Semiconductor Processing, vol. 39, pp. 223-228, 2015.

[11] C. C. Ting and W. S. Chao, "Efficiency improvement of the DSSCs by building the carbon black as bridge in photo electrode," Applied Energy, vol. 87, no. 8, pp. 2500-2505, 2010.

[12] W. Maiaugree, S. Lowpa, M. Towannang et al., "A dye sensitized solar cell using natural counter electrode and natural dye derived from mangosteen peel waste," Scientific Reports, vol. 5, p. 15230, 2015.

[13] A. Sahasrabudhe, S. Kapri, and S. Bhattacharyya, "Graphitic porous carbon derived from human hair as 'green' counter electrode in quantum dot sensitized solar cells," Carbon, vol. 107, pp. 395-404, 2016.

[14] M. Pakula, S. Biniak, and A. Swiatkowski, "Chemical and electrochemical studies of interactions between iron (III) ions and an activated carbon surface," Langmuir, vol. 14, no. 11, pp. 3082-3089, 1998.

[15] J. Guo and A. C. Lua, "Textural and chemical characterizations of activated carbon prepared from oil-palm stone with $\mathrm{H}_{2} \mathrm{SO}_{4}$ and $\mathrm{KOH}$ impregnation," Microporous and Mesoporous Materials, vol. 32, no. 1, pp. 111-117, 1999.

[16] O. Gercel, A. Ozcan, A. Safa Ozcan, and H. Ferdi Gercel, "Preparation of activated carbon from a renewable bio-plant of Euphorbia rigida by $\mathrm{H}_{2} \mathrm{SO}_{4}$ activation and its adsorption behavior in aqueous solutions," Applied Surface Science, vol. 253, no. 11, pp. 4843-4852, 2007.

[17] M. Chen, L. L. Shao, Y. P. Liu, T. Z. Ren, and Z. Y. Yuan, "Nitrogen-doped ordered cubic mesoporous carbons as metal-free counter electrodes for dye-sensitized solar cells," Journal of Power Sources, vol. 283, pp. 305-313, 2015.

[18] W. Yang, X. Ma, X. Xu et al., "Sulfur-doped porous carbon as metal-free counter electrode for high efficiency dye-sensitized 
solar cells," Journal of Power Sources, vol. 282, pp. 228-234, 2015.

[19] W. Si, J. Zhou, S. Zhang, S. Li, W. Xing, and S. Zhuo, “Tunable $\mathrm{N}$-doped or dual N, S-doped activated hydrothermal carbons derived from human hair and glucose for supercapacitor applications," Electrochimica Acta, vol. 107, pp. 397-405, 2013.

[20] Z. Guo, Q. Zhou, Z. Wu et al., "Nitrogen-doped carbon based on peptides of hair as electrode materials for supercapacitors," Electrochimica Acta, vol. 113, pp. 620-627, 2013.

[21] E. Tamburri, V. Guglielmotti, S. Orlanducci, and M. L. Terranova, "Structure and $\mathrm{I}_{2} / \mathrm{I}^{-}$redox catalytic behaviour of PEDOT-PSS films electro polymerized in aqueous medium: implications for convenient counter electrodes in DSSC," Inorganica Chimica Acta, vol. 377, no. 1, pp. 170-176, 2011.

[22] G. Yue, J. Wu, Y. Xiao, J. Lin, and M. Huang, "Low cost poly(3,4-ethylenedioxythiophene):polystyrenesulfonate/carbon black counter electrode for dye-sensitized solar cells," Electrochimica Acta, vol. 67, pp. 113-118, 2012.

[23] M. Belekoukia, M. S. Ramasamy, S. Yang et al., "Electrochemically exfoliated graphene/PEDOT composite films as efficient Pt-free counter electrode for dye-sensitized solar cells," Electrochimica Acta, vol. 194, pp. 110-115, 2016.

[24] C. P. Lee, C. A. Lin, T. C. Wei et al., "Economical low-light photovoltaics by using the Pt-free dye-sensitized solar cell with graphene dot/PEDOT:PSS counter electrodes," Nano Energy, vol. 18, pp. 109-117, 2015.

[25] A. Nikolakopoulou, D. Tasis, L. Sygellou, V. Dracopoulos, C. Galiotis, and P. Lianos, "Study of the thermal reduction of graphene oxide and of its application as electrocatalyst in quasisolid state dye-sensitized solar cells in combination with PEDOT," Electrochimica Acta, vol. 111, pp. 698-706, 2013.

[26] H. J. Shin, S. S. Jeon, and S. S. Im, "CNT/PEDOT core/ shell nanostructures as a counter electrode for dye-sensitized solar cells," Synthetic Metals, vol. 161, no. 13-14, pp. 12841288, 2011.

[27] J. Y. Lin, W. Y. Wang, and S. W. Chou, "Flexible carbon nanotube/polypropylene composite plate decorated with poly $(3,4-$ ethylenedioxythiophene) as efficient counter electrodes for dye-sensitized solar cells," Journal of Power Sources, vol. 282, pp. 348-357, 2015.

[28] A. M. M. Santos and W. L. Vasconcelos, "Obtention of nanostructured silica glass by sol-gel process with incorporation of lead compounds," Materials Research, vol. 2, no. 3, pp. 201204, 1999.

[29] S. J. V. Gaast and A. J. Vaars, "A method to eliminate the background in X-ray diffraction patterns of oriented clay mineral samples," Clay Minerals, vol. 16, no. 4, pp. 383-393, 1981.

[30] A. K. Kercher and D. C. Nagle, "Microstructural evolution during charcoal carbonization by X-ray diffraction analysis," Carbon, vol. 41, no. 1, pp. 15-27, 2003.

[31] T. Jawhari, A. Roid, and J. Casado, "Raman spectroscopic characterization of some commercially available carbon black materials," Carbon, vol. 33, no. 11, pp. 1561-1565, 1995.

[32] W. Kwon, J. M. Kim, and S. W. Rhee, "Electrocatalytic carbonaceous materials for counter electrodes in dye-sensitized solar cells," Journal of Materials Chemistry a, vol. 1, no. 10, pp. 3202-3215, 2013.

[33] J. M. Kim and S. W. Rhee, "Electrochemical properties of porous carbon black layer as an electron injector into iodide redox couple," Electrochimica Acta, vol. 83, pp. 264-270, 2012.
[34] X. Qiao, S. Liao, C. You, and R. Chen, "Phosphorus and nitrogen dual doped and simultaneously reduced graphene oxide with high surface area as efficient metal-free electrocatalyst for oxygen reduction," Catalysts, vol. 5, no. 2, pp. 981-991, 2015.

[35] L. Geng, S. Wu, Y. Zou et al., "Correlation between the microstructures of graphite oxides and their catalytic behaviors in air oxidation of benzyl alcohol," Journal of Colloid and Interface Science, vol. 421, pp. 71-77, 2014.

[36] X. Wu, X. Yu, Z. Lin et al., "Nitrogen doped graphitic carbon ribbons from cellulose as non noble metal catalyst for oxygen reduction reaction," International Journal of Hydrogen Energy, vol. 41, no. 32, pp. 14111-14122, 2016.

[37] C. R. Robbins and M. K. Bahl, "Analysis of hair by electron spectroscopy for chemical analysis," Society of Cosmetic Chemists, vol. 35, pp. 379-390, 1984.

[38] C. R. Robbins, Chapter 2 Chemical Composition of Different Hair Types, Springer-Verlag, Berlin Heidelberg, 2012.

[39] T. Ujva'ri, A. Kolitsch, A. To'th, M. Mohai, and I. Berto'ti, "XPS characterization of the composition and bonding states of elements in CNx layers prepared by ion beam assisted deposition," Diamond and Related Materials, vol. 11, no. 3, pp. 1149-1152, 2002.

[40] G. M. Burke, D. E. Wurster, M. J. Berg, P. V. Pedersen, and D. D. Schottelius, "Surface characterization of activated charcoal by X-ray photoelectron spectroscopy (XPS): correlation with phenobarbital adsorption data," Pharmaceutical Research, vol. 9, no. 1, pp. 126-130, 1992.

[41] National Institute of Standards and Technology (NIST), "XPS database," 2012, http://srdata.nist.gov/xps/EnergyType ValSrch.aspx/.

[42] A. I. Popov and D. H. Geske, "Studies on the chemistry of halogen and of polyhalides. XIII. Voltammetry of iodine species in acetonitrile," Journal of the American Chemical Society, vol. 80, no. 6, pp. 1340-1352, 1958.

[43] Z. Huang, X. Liu, K. Li et al., "Application of carbon materials as counter electrodes of dye-sensitized solar cells," Electrochemistry Communications, vol. 9, no. 4, pp. 596-598, 2007.

[44] W. Kwon, J. M. Kim, and S. W. Rhee, "A new equivalent circuit model for porous carbon electrodes in charge transfer reaction of iodide/triiodide redox couples," Electrochimica Acta, vol. 68, pp. 110-113, 2012.

[45] Q. Wang, S. Ito, M. Grätzel et al., "Characteristics of high efficiency dye-sensitized solar cells," Journal of Physical Chemistry $B$, vol. 110 , no. 50, pp. 25210-25221, 2006.

[46] W. Maiaugree, A. Tangtrakarn, S. Lowpaa, N. Ratchapolthavisinb, and V. Amornkitbamrung, "Facile synthesis of bilayer carbon $/ \mathrm{Ni}_{3} \mathrm{~S}_{2}$ nanowalls for a counter electrode of dyesensitized solar cell," Electrochimica Acta, vol. 174, pp. 955962, 2015.

[47] C. T. Li, C. T. Lee, S. R. Li et al., "Composite films of carbon black nanoparticles and sulfonatedpolythiophene as flexible counter electrodes for dye-sensitized solar cells," Journal of Power Sources, vol. 302, pp. 155-163, 2016.

[48] R. Katoh and A. Furube, "Electron injection efficiency in dye-sensitized solar cells," Journal of Photochemistry and Photobiology C, vol. 20, no. 1, pp. 1-16, 2014.

[49] M. Wu and T. Ma, "Platinum-free catalysts as counter electrodes in dye-sensitized solar cells," ChemSusChem, vol. 5, no. 8, pp. 1343-1357, 2012. 

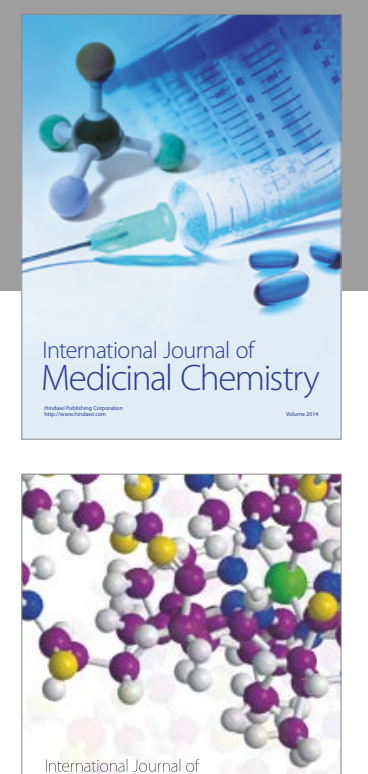

Carbohydrate Chemistry

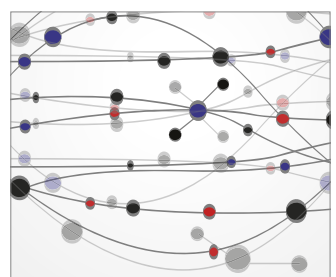

The Scientific World Journal
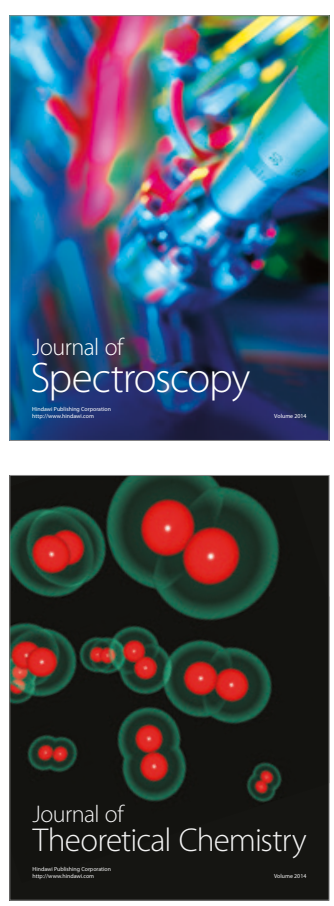
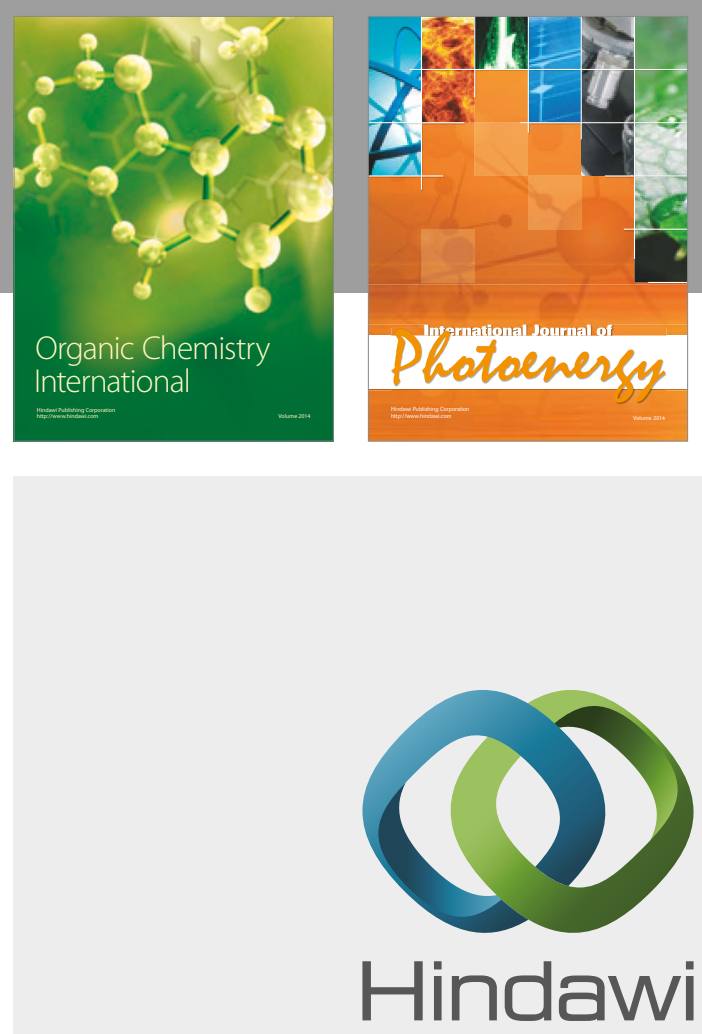

Submit your manuscripts at

https://www.hindawi.com

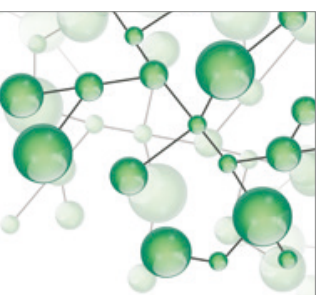

International Journal of

Inorganic Chemistry

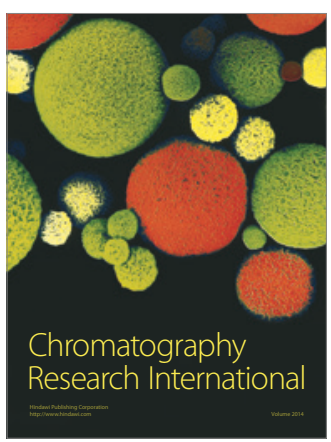

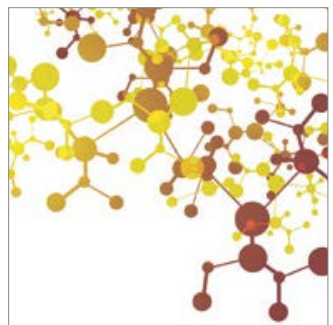

Applied Chemistry
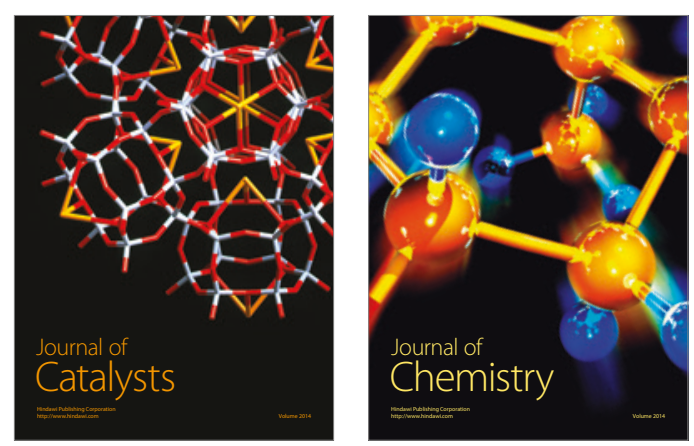
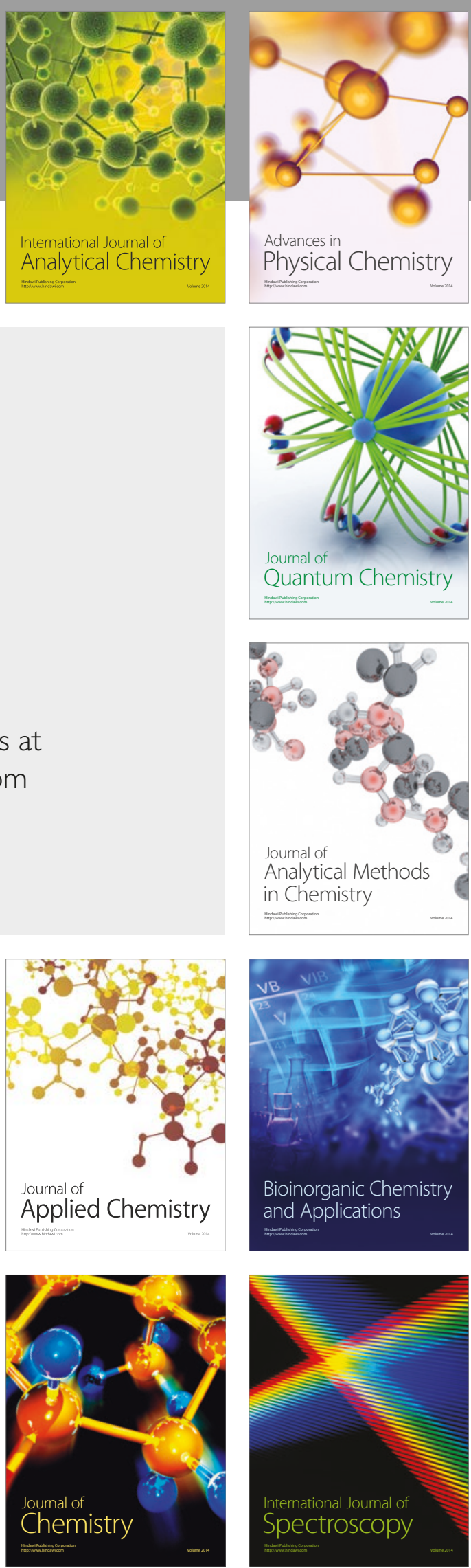